\title{
A Cost Effective Multi-Spectral Scanner for Natural Gas Detection
}

\author{
Semi-Annual Progress Report No. 4
}

Reporting Period Start Date: April 1, 2005

Reporting Period End Date: September 30, 2005

Principal Authors: Yudaya Sivathanu, Jongmook Lim, Vinoo Narayanan, and Seonghyeon Park

Issue Date: December 7, 2005

Contract Number: DE-FC26-03NT41857

Submitting Organization: En’Urga Inc.

1291-A, Cumberland Avenue

West Lafayette, IN 47906 
Semi-Annual Progress Report No. 4

on

\section{A Cost Effective Multi-Spectral Scanner for Natural Gas Detection}

Yudaya Sivathanu, Jongmook Lim, Vinoo Narayanan, and Seonghyeon Park

\section{DISCLAIMER NOTICE}

This report was prepared as an account of work sponsored by an agency of the United States Government. Neither the United States Government nor any agency thereof, nor any of their employees, makes any warranty, express or implied, or assumes any legal liability or responsibility for the accuracy, completeness, or usefulness of any information, apparatus, product, or process disclosed, or represents that its use would not infringe privately owned rights. Reference herein to any specific commercial product, process, or service by trade name, trademark, manufacturer, or otherwise does not necessarily constitute or imply its endorsement, recommendation, or favoring by the United States Government or any agency thereof. The views and opinions of authors expressed herein do not necessarily state or reflect those of the United States Government or any agency thereof. 


\title{
A Cost Effective Multi-Spectral Scanner for Natural Gas Detection
}

\begin{abstract}
The objective of this project is to design, fabricate and field demonstrate a cost effective, multi-spectral scanner for natural gas leak detection in transmission and distribution pipelines. During the first year of the project, a laboratory version of the multi-spectral scanner was designed, fabricated, and tested at En'Urga Inc. The multi-spectral scanner was also evaluated using a blind DoE study at RMOTC. The performance of the scanner was inconsistent during the blind DoE study. However, most of the leaks were outside the view of the multi-spectral scanner. Therefore, a definite evaluation of the capability of the scanner was not obtained. Despite the results, sufficient number of plumes was detected fully confirming the feasibility of the multi-spectral scanner. During the second year, the optical design of the scanner was changed to improve the sensitivity of the system. Laboratory tests show that the system can reliably detect small leaks (20 SCFH) at 30 to 50 feet. Electronic and mechanical design of the scanner to make it a self standing sensor was completed during the last six months of the project. The prototype scanner was tested with methane leaks at 15 feet and 30 feet, at a flow rate of 25 SCFH. The prototype scanner successfully detected the leaks. This concluded the project.
\end{abstract}




\section{TABLE OF CONTENTS}

\section{Title Page}

Disclaimer Notice $\quad$...................................................................... 1

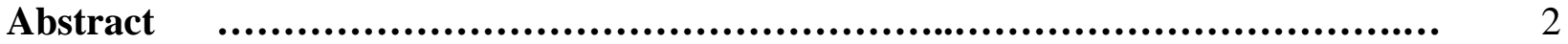

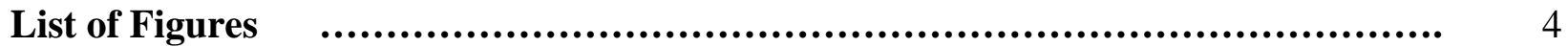

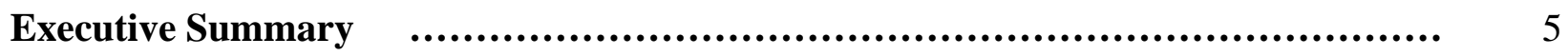

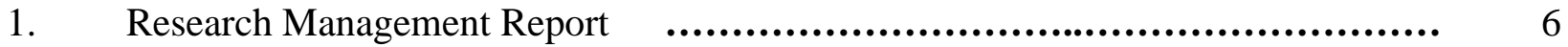

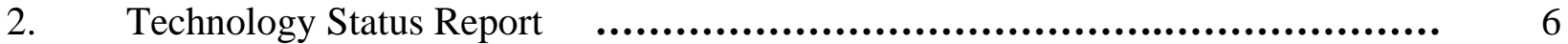

3. Design and Fabrication of Laboratory Scale Scanner $\quad$................................ 8

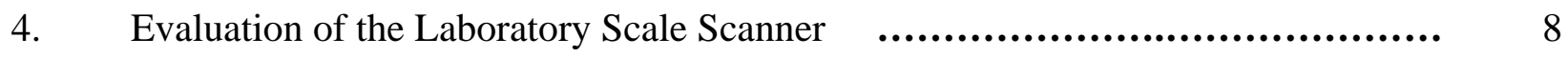

5. Development of the Prototype Scanner $\quad$.............................................. 9

$5.1 \quad$ Optical Design of the Prototype Scanner $\quad$.................................. 9

5.2 Electronic Design of the Prototype Scanner $\quad$................................ 9

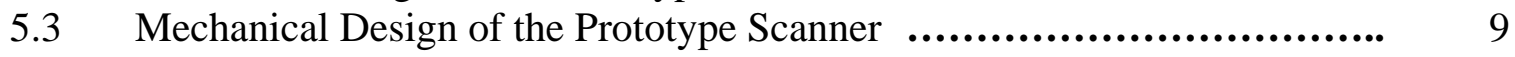

6. Evaluation of the Prototype Scanner $\quad$....................................... 10

7. Conclusions and Recommendations $\quad$......................................... 12 


\section{List of Figures}

Figure Title $\quad \underline{\text { Page No. }}$

Figure 1. Photograph of the laboratory scale scanner mounted on a tripod. ............... 8

Figure 2. Photographs the prototype scanner. $\quad$....................................... 9

Figure 3. Photograph of the modified prototype scanner. $\quad$............................... 10

Figure 4. Photograph of the arrangement used to evaluate the prototype scanner. $\quad$....... 11

Figure 5. Sample results obtained from the prototype scanner. $\quad$....................... 11 


\section{A Cost Effective Multi-Spectral Scanner for Natural Gas Detection}

\section{Executive Summary}

The objective of this project is to design, fabricate and field demonstrate a cost effective, multi-spectral scanner for natural gas leak detection in transmission and distribution pipelines. The six specific tasks required for the completion of the project are: (1) Development of the research management plan, (2) Assessment of current technology, (3) Design and fabrication of a laboratory scale multi-spectral scanner, (4) Evaluation of the laboratory scale multi-spectral scanner, (5) Design and fabrication of a prototype multi-spectral scanner, and (6) evaluation of the prototype multi-spectral scanner.

The first task, which is the development of the research management plan, was completed during this report period. The research management plan has been submitted to the Department of Energy, NETL. This task was completed within the scheduled time.

The second task, which is the assessment of current technology, has been completed. A report has been submitted to the Department of Energy, NETL. In addition, an overview of the entire project was provided to NETL at a kickoff meeting on December 16. This task was also completed within the schedule time.

The third task is the design and fabrication of a laboratory scale multi-spectral scanner. The three components of the design are the optical design, mechanical design, and the electronic design for the scanner. The optical design for the scanner was completed using Zemax optical design software. The electronic design for the scanner was completed using Protel Electronic Design software. The scanner housing design was completed using ProEngineer software package. The mechanical engineering design is modular in nature with the scanner and optics in one module and the detector and PCB in another module. The housing for the scanner was fabricated and integrated into one package for evaluation.

The fourth task was the evaluation of the laboratory scale scanner. The scanner was initially evaluated at En'Urga Inc. with a 10 SCFH leak of natural gas. The scanner could detect the leak while it was stationary. Further evaluation was conducted using a DoE organized test at RMOTC. Performance of the laboratory version of the multi-spectral scanner was satisfactory. However, further improvement in performance is required for vehicle mounted operations.

During the second year of the project, a rugged prototype version of the multi-spectral scanner was designed and fabricated. This was the fifth task of the project. The prototype version is a stand-alone sensor that can be directly operated on batteries. The final task of the project was the evaluation of the prototype sensor. The sensor was evaluated at En'Urga Inc. using a 25 SCFH leak. The sensor successfully detected the leak at distances of 15 feet and 30 feet. The signals obtained were successfully displayed directly on a LCD display.

Further improvements and evaluation of the sensor are required before commercialization of the sensor can begin. 


\section{A Cost Effective Multi-Spectral Scanner for Natural Gas Detection}

The report is divided into five parts, corresponding to the different tasks completed during the first twelve months of the project, corresponding to the milestone chart.

\section{Research Management Report}

The first task of the project was the development of a research management report. The list of deliverables and target dates for the project are shown in Table 1.

Table 1: List of Deliverable and Target Dates

\begin{tabular}{|c|l|l|}
\hline Item No. & \multicolumn{1}{|c|}{ Deliverable } & \multicolumn{1}{c|}{ Target Date } \\
\hline 1 & Research management plan & October 31, 2003 \\
\hline 2 & Technology status report/briefing & November 30, 2003 \\
\hline 3 & First bi-annual report & April 15, 2004 \\
\hline 4 & Second bi-annual report & October 15, 2004 \\
\hline 5 & Conference presentation & October 15, 2004 \\
\hline 6 & Third bi-annual report & April 15, 2004 \\
\hline 7 & Final report/briefing & October 15, 2004 \\
\hline 8 & Informal reports & Monthly \\
\hline
\end{tabular}

The list of milestones for the project, with target dates are shown in Table 2.

Table 2: List of Milestone with Target Dates

\begin{tabular}{|c|l|l|}
\hline Item No. & \multicolumn{1}{|c|}{ Milestones } & \multicolumn{1}{c|}{ Target Date } \\
\hline 1 & Laboratory scanner design & February 29,2004 \\
\hline 2 & $\begin{array}{l}\text { Laboratory scanner } \\
\text { fabrication/calibration }\end{array}$ & May 29,2004 \\
\hline 3 & Laboratory scanner evaluation & September 30, 2004 \\
\hline 4 & Prototype PCB design and fabrication & January 31, 2005 \\
\hline 5 & $\begin{array}{l}\text { Prototype scanner } \\
\text { fabrication/calibration }\end{array}$ & May 31, 2005 \\
\hline 6 & Prototype scanner evaluation & September 15, 2005 \\
\hline
\end{tabular}

A detailed description of the deliverables and milestones was provided to DOE during the first month of the project.

\section{Technology Status Report}

The second task of the project was the creation of a technology status report. The technology status report highlighted the current status of pipeline leak detection. A summary comparison of the different natural gas leak detection techniques is provided in Table 3. 
Table 3: Comparison of Different Natural Gas Leak Detection Techniques

\begin{tabular}{|c|c|c|c|}
\hline Technique & Feature & Advantages & Disadvantages \\
\hline $\begin{array}{l}\text { Acoustic } \\
\text { sensors }\end{array}$ & $\begin{array}{l}\text { Detects leaks based on } \\
\text { acoustic emission }\end{array}$ & $\begin{array}{l}\text { Portable } \\
\text { Location identified } \\
\text { Continuous monitor }\end{array}$ & $\begin{array}{l}\text { High cost } \\
\text { Prone to false alarms } \\
\text { Not suitable for small } \\
\text { leaks }\end{array}$ \\
\hline Gas sampling & $\begin{array}{l}\text { Flame Ionization detector } \\
\text { used to detect natural gas }\end{array}$ & $\begin{array}{l}\text { No false alarms } \\
\text { Very sensitive } \\
\text { Portable } \\
\end{array}$ & $\begin{array}{l}\text { Time consuming } \\
\text { Expensive } \\
\text { Labor intensive } \\
\end{array}$ \\
\hline Soil monitoring & $\begin{array}{l}\text { Detects tracer chemicals } \\
\text { added to gas pipe line }\end{array}$ & $\begin{array}{l}\text { Very sensitive } \\
\text { No false alarms } \\
\text { Portable }\end{array}$ & $\begin{array}{l}\text { Need chemicals and } \\
\text { therefore expensive } \\
\text { Time consuming }\end{array}$ \\
\hline $\begin{array}{l}\text { Flow } \\
\text { monitoring }\end{array}$ & $\begin{array}{l}\text { Monitor either pressure } \\
\text { change or mass flow }\end{array}$ & $\begin{array}{l}\text { Low cost } \\
\text { Continuous monitor } \\
\text { Well developed }\end{array}$ & $\begin{array}{l}\text { Prone to false alarms } \\
\text { Unable to pinpoint } \\
\text { leaks }\end{array}$ \\
\hline $\begin{array}{l}\text { Dynamic } \\
\text { modeling }\end{array}$ & $\begin{array}{l}\text { Monitored flow } \\
\text { parameters modeled }\end{array}$ & $\begin{array}{l}\text { Portable } \\
\text { Continuous monitor }\end{array}$ & $\begin{array}{l}\text { Prone to false alarms } \\
\text { Expensive }\end{array}$ \\
\hline Lidar absorption & $\begin{array}{l}\text { Absorption of a pulsed } \\
\text { laser monitored in the } \\
\text { infrared }\end{array}$ & $\begin{array}{l}\text { Remote monitoring } \\
\text { Sensitive } \\
\text { Portable }\end{array}$ & $\begin{array}{l}\text { Expensive sources } \\
\text { Alignment difficult } \\
\text { Short system life time }\end{array}$ \\
\hline $\begin{array}{l}\text { Diode laser } \\
\text { absorption }\end{array}$ & $\begin{array}{l}\text { Absorption of diode lasers } \\
\text { monitored }\end{array}$ & $\begin{array}{l}\text { Remote monitoring } \\
\text { Portable } \\
\text { Long range }\end{array}$ & $\begin{array}{l}\text { Prone to false alarms } \\
\text { Expensive sources } \\
\text { Short system life time }\end{array}$ \\
\hline $\begin{array}{l}\text { Broad band } \\
\text { absorption }\end{array}$ & $\begin{array}{l}\text { Absorption of broad band } \\
\text { lamps monitored }\end{array}$ & $\begin{array}{l}\text { Portable } \\
\text { Remote monitoring } \\
\text { Long range }\end{array}$ & $\begin{array}{l}\text { Prone to false alarms } \\
\text { Short system life time }\end{array}$ \\
\hline $\begin{array}{l}\text { Evanescent } \\
\text { sensing }\end{array}$ & $\begin{array}{l}\text { Monitors changes in } \\
\text { buried optical fiber }\end{array}$ & $\begin{array}{l}\text { Long lengths can be } \\
\text { monitored easily }\end{array}$ & $\begin{array}{l}\text { Prone to false alarms } \\
\text { Expensive system }\end{array}$ \\
\hline $\begin{array}{l}\text { Millimeter wave } \\
\text { radar systems }\end{array}$ & $\begin{array}{l}\text { Radar signature obtained } \\
\text { above pipe lines }\end{array}$ & $\begin{array}{l}\text { Remote monitoring } \\
\text { Portable }\end{array}$ & Expensive \\
\hline $\begin{array}{l}\text { Backscatter } \\
\text { imaging }\end{array}$ & $\begin{array}{l}\text { Natural gas illuminated } \\
\text { with CO2 laser }\end{array}$ & $\begin{array}{l}\text { Remote monitoring } \\
\text { Portable }\end{array}$ & Expensive \\
\hline $\begin{array}{l}\text { Thermal } \\
\text { imaging }\end{array}$ & $\begin{array}{l}\text { Passive monitoring of } \\
\text { thermal gradients }\end{array}$ & $\begin{array}{l}\text { No sources needed } \\
\text { Portable } \\
\text { Remote monitoring }\end{array}$ & $\begin{array}{l}\text { Expensive detector } \\
\text { Requires temperature } \\
\text { difference }\end{array}$ \\
\hline $\begin{array}{l}\text { Multi-spectral } \\
\text { imaging }\end{array}$ & $\begin{array}{l}\text { Passive monitoring using } \\
\text { multi-wavelength infrared } \\
\text { imaging }\end{array}$ & $\begin{array}{l}\text { No sources need } \\
\text { Portable } \\
\text { Remote monitoring } \\
\text { Multiple platform } \\
\text { choices }\end{array}$ & $\begin{array}{l}\text { Expensive detectors } \\
\text { Difficult data } \\
\text { interpretation }\end{array}$ \\
\hline
\end{tabular}

The technology status report was completed and delivered to DOE at the end of the second month of the project. 


\section{Design and Fabrication of the Laboratory Scale Scanner}

The third task is the design and fabrication of the laboratory scale scanner. The optical design for the multi-spectral scanner was completed using a ray-tracing algorithm (Zeemax). The electronic design of the circuit boards for the scanner was completed using a PCB design and layout software (Protel). The mechanical design was completed using a solid modeling package (ProEngineering). The circuit boards and the scanner housing were fabricated using outside vendors. A photograph of the final laboratory scale scanner is shown in Fig. 1.

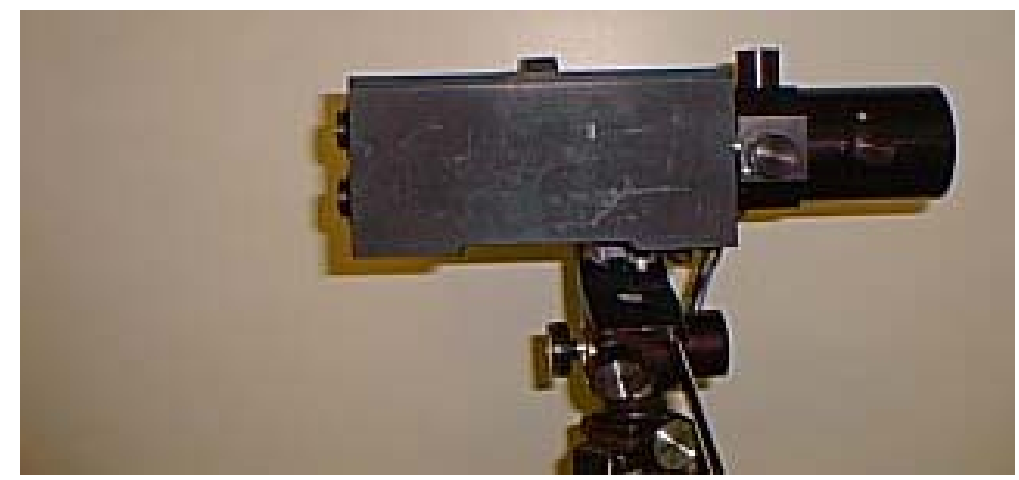

Figure 1. Photograph of the laboratory scale scanner mounted on a tripod.

The scanner essentially consists of a four element, thermoelectrically cooled, lead selenide array with a 2-dimension scanner and associated optical elements to image a scene at four wavelengths. The power for the scanner and the four element sensor was supplied from an external power supply box, and the data was read out using a laboratory computer and a high speed data acquisition board.

\section{Evaluation of the Laboratory Scale Scanner}

The fourth task was to evaluate the scanner. First the scanner was evaluated at En'Urga Inc. using a small natural gas leak at En'Urga Inc. It was successful in detecting small leaks as long as the entire system was stationary, and the leak was near the sensor. A blackbody was also used for these tests, providing a very stable background. The scanner was then mounted inside a moving van and tested at RMOTC. The following conclusions were obtained form the tests.

1 Small leaks that are more than 50 feet from road cannot be detected when the multispectral scanner is configured to scan only up to 50 feet from the mount location.

2. The exact leak location cannot be determined unless the vehicle-mounted scanner is riding on top of the pipeline. If the scanner is on a moving platform and scanning some distance to the side, only approximate locations of the plume itself can be ascertained.

3. For future tests, it would be desirable to have an access way on top of the pipeline. Failing that, all leaks should be located within 50 feet from the middle of the road, or 
prior notice of the maximum distance of the leak location from the road should be provided.

4. Only one portion of the road could be scanned on each pass since the entire pipeline had to be inspected at $2 / 3^{\text {rd }}$ the speed of an aircraft inspection.

\section{Development of Prototype Scanner}

The first task during the second year (fifth task for the overall project) of the project is to develop a prototype scanner. The following describes the progress made on three key subtasks associated with the development of the prototype scanner.

\subsection{Optical Design of the Prototype Scanner}

The optical design of the prototype scanner was completed during the first six months of the project.

\subsection{Electronic Design of the Prototype Scanner}

The electronic design of the prototype scanner was also completed during the first six months of the project. A microprocessor was used to directly collect data from the four element sensor and display it on the screen. The microprocessor was then programmed to utilize the data from the different detectors and obtain a ratio of intensities. This is required for directly displaying leaks from the pipelines onto the LCD display. This was completed during the last three months of the project.

\subsection{Mechanical Design of the Prototype Scanner}

The last subtask ws to complete the mechanical design and fabrication of the prototype scanner. The entire device had to packaged into a stand-alone system that can be operated directly from a battery. The mechanical design of the housing was completed on ProEngineer solid modeling package. Two photographs of the resulting prototype scanner is shown in Fig. 2.
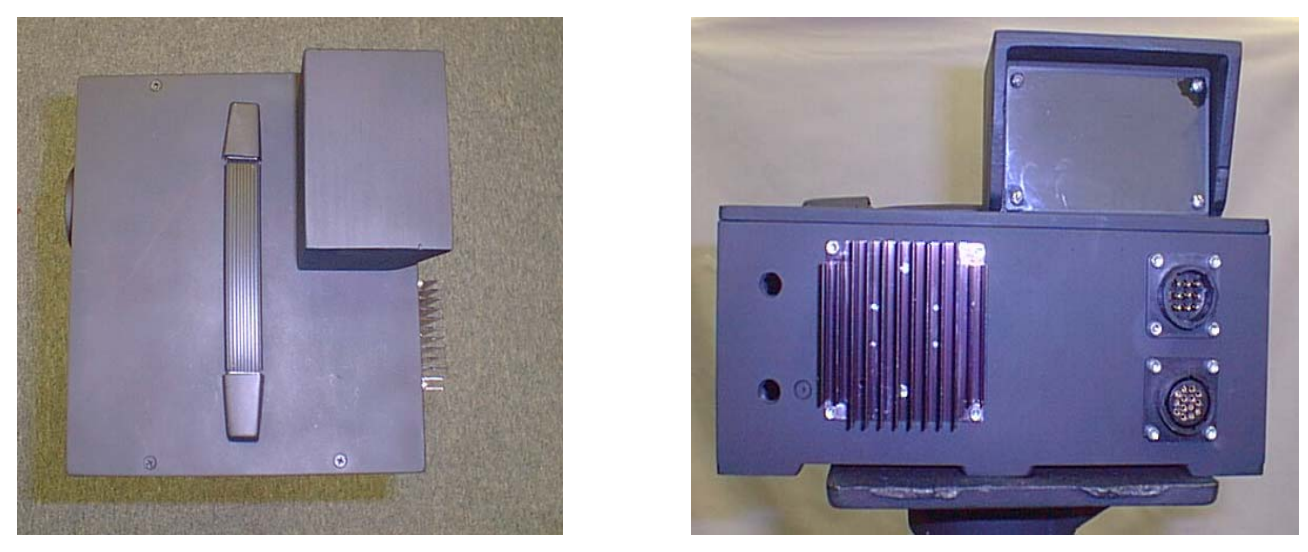

Figure 2. Photographs of the prototype scanner. 
The prototype scanner is approximately 10 "x9X"x5". It can be either mounted on a tripod or carried using a handle (shown on the left side photograph). The entire scanner weights about 14 lbs. The scanner has a back-facing mount for the LCD display (shown on the right side photography). In addition, two connectors, one for the power, and another for the data downloads are also on the back surface of the prototype scanner. Provisions for purging the interior of the prototype scanner has also been provided.

During the initial tests, the backward facing LCD screen had some problems with maintaining the integrity of the housing. The purge air used to check the integrity of the housing showed extensive leaks through the backward facing mount. This is not acceptable since in service, the entire unit can get easily coated with dust, and the leakage would result in dust entering the housing. Therefore, it was decided to mount the LCD screen directly on the scanner housing, using a rubber gasket. This modification was accomplished and the resulting prototype scanner is shown in Fig. 3.

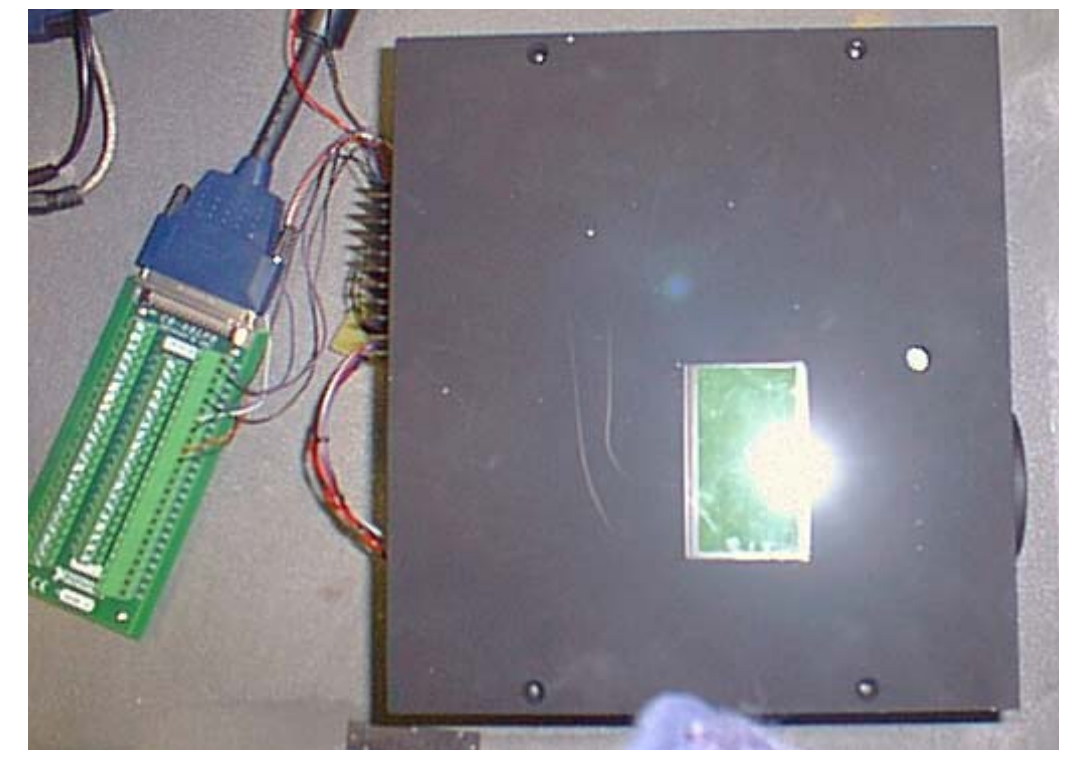

Figure 3. Photograph of the modified prototype scanner.

In addition to the LCD display, there is also a breakout terminal that enables the output from the channels to be sample and stored in a computer. The breakout terminal is also shown in Fig. 3. This completed Task 5 of the project.

\section{Evaluation of Prototype Scanner}

The last task of the project was the evaluation of the prototype scanner. The scanner was turned on and data collected using the breakout box. The experimental arrangement used to collect the data is shown in Fig. 4. 


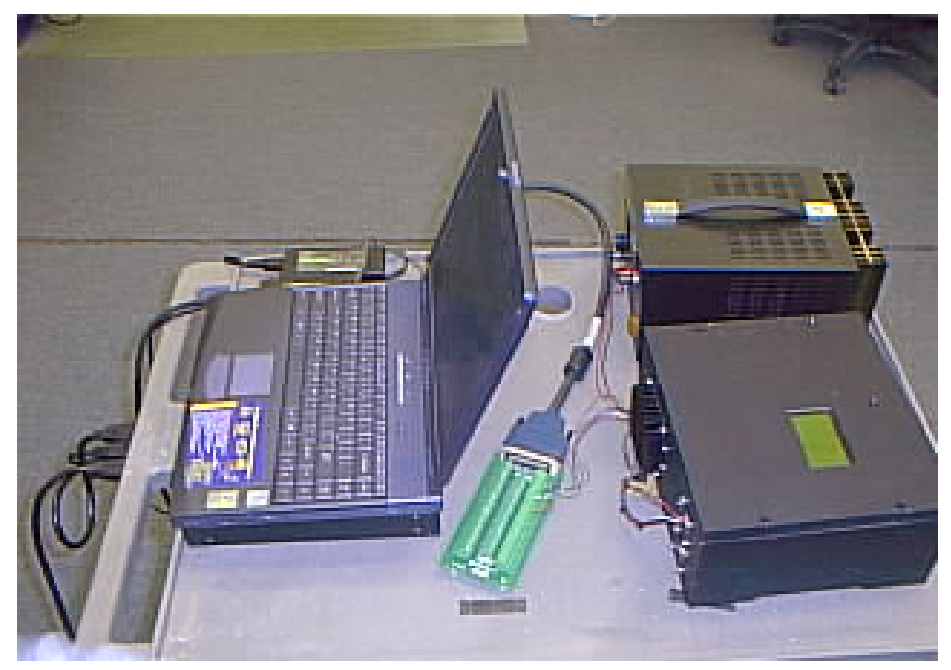

Figure 4. Photograph of the arrangement used to evaluate the prototype scanner.

The data was directly displayed on the LCD panel. In addition, the data was collected on a laptop computer for analysis. The prototype scanner was evaluated, with and without a 25 SCFH flow of methane in its path. Sample results obtained from four separate scans are shown in Fig. 5. Two of the scans, shown by the blue and cyan lines, were obtained without any gas

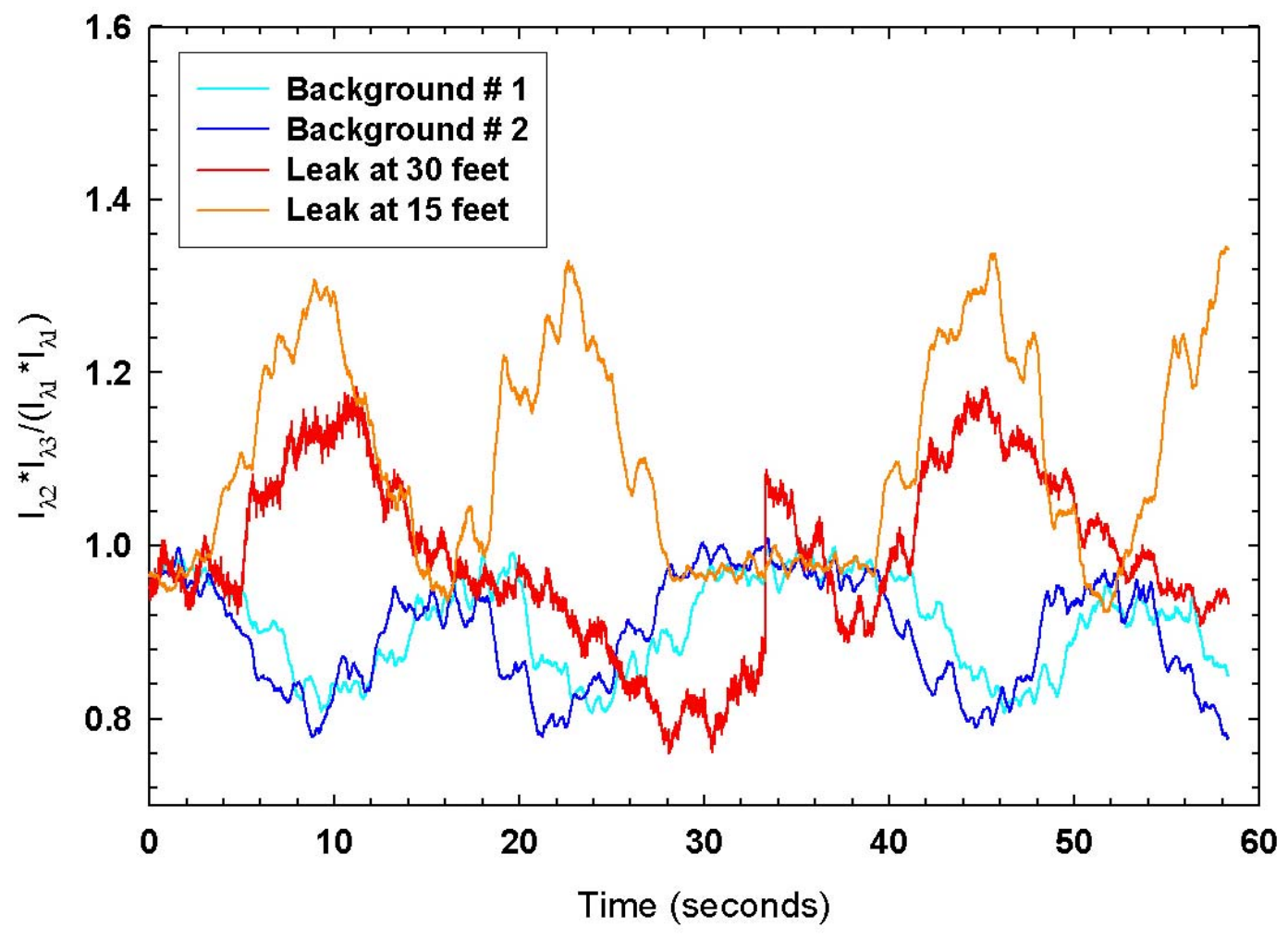

Figure 5. Sample results obtained from the prototype scanner. 
flow in the path of the prototype scanner. The intensity ratios are plotted as a function of time for approximately one minute. The intensity ratio moves up and down, due to the changes in the emissivity of the surroundings. For two of the scans, methane at 25 SCFH was flowed through a quarter inch tube at distances of 15 feet and 30 feet from the prototype scanner. The intensity at the first wavelength, $\mathrm{I}_{\lambda_{1}}$ is at 3.4 microns, and the intensity at the second and third wavelengths, $\mathrm{I}_{\lambda 2}$ is $\mathrm{I}_{\lambda_{3}}$ is at 3.8 and 4.0 microns.

When there is methane in the path, some of the background radiation is absorbed only at the first wavelength. Therefore, the ratio of intensities will increase. This is clearly seen in the results. The width of the plume is much bigger than the $6 \mathrm{~mm}$ tube used for the leaks. In some cases, when methane disperses too much, it is difficult to make out the plume very distinctly from the background.

When the prototype scanner is placed within 15 feet of the leak, the ratio of the intensities obtained is as high as 1.4 . This is approximately $40 \%$ than the peak observed without any methane. When the prototype scanner is placed within 30 feet of the leak, the ratio of intensities is as high as approximately 1.18 . This is approximately $18 \%$ higher than the maximum observed without any methane. Therefore, it is clear that the prototype scanner can clearly see a natural gas leak from 30 feet. Similar information is also obtained from the LCD display. This completed the last task of the project.

\section{Conclusions and Recommendations}

The following conclusions can be obtained from the project.

1. A laboratory scale multi-wavelength scanner was developed and evaluated during the first year of the project. The scanner was designed to operate directly over the pipeline and in all instances, within 50 feet from the leak.

2. The laboratory scale scanner performed adequately during in-house trials. During the initial field evaluations at RMOTC, the large distance to the leaks prevented a critical evaluation of the technology.

3. A prototype stand-alone natural gas detector was developed and evaluated during the second year of the project.

4. The prototype detector can clearly discern natural gas pipeline leaks of 25 SCFH at a distance of 30 feet from the detector.

5. Further field evaluations of the detector is required to fully understand the limits of detectibility with the system.

It is recommended that further development of the scanner be undertaken, either under a

Small Business Innovation Research grant or private funding before commercialization of the scanner. 